Levitsky A. P., Stepan V. T., Pustovoit P. I. Comparative nephrotoxic effect on rats of different pathogens. Journal of Education, Health and Sport. 2020;10(10):212-218. eISSN 2391-8306. DOI http://dx.doi.org/10.12775/JEHS.2020.10.10.019 https://apcz.umk.pl/czasopisma/index.php/JEHS/article/view/JEHS.2020.10.10.019

https://zenodo.org/record/4309864

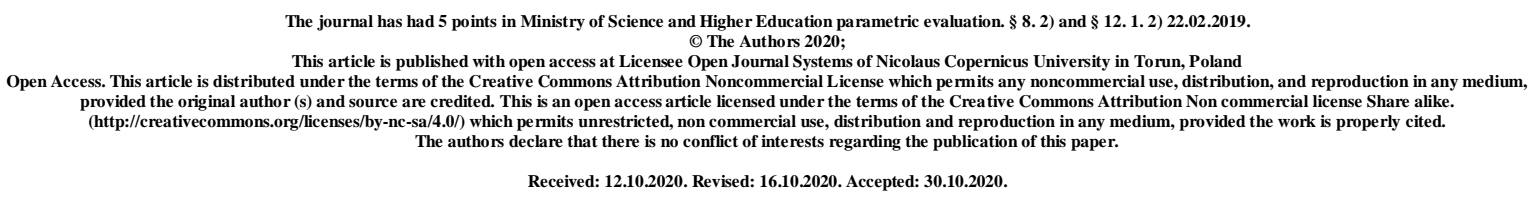

UDK 616.61:616.34:616.35:612.3:577.15

\title{
COMPARATIVE NEPHROTOXIC EFFECT ON RATS OF DIFFERENT PATHOGENS
}

\author{
A. P. Levitsky ${ }^{1}$, V. T. Stepan ${ }^{2}$, P. I. Pustovoit ${ }^{3}$ \\ ${ }^{1}$ Odessa National Academy of Food Technologies \\ ${ }^{2}$ Bukovina State Medical University, Chernovtsy \\ ${ }^{3}$ Municipal Institution «Odessa Regional Clinical Hospital»
}

Abstract

Aim. Compare the nephrotoxicity of different pathogens.

Methods. Nephrotoxicity was assessed in rats treated with the following pathogens: hydrazine sulfate, prednisolone, cyclophosphamide, lincomycin and lipopolysaccharide, according to the degree of increase in biochemical markers of inflammation: elastase activity and malondialdehyde (MDA) content.

Result. A significant increase in the level of both inflammatory markers in the kidneys was established, the most pronounced under the influence of hydrazine sulfate. The recalculation of the percentage increase in the level of markers per $1 \mathrm{mg}$ of the pathogen (specific pro-inflammatory activity, SPIA) showed the highest SPIA in lipopolysaccharide, especially after oral applications, exceeding SPIA for hydrazine sulfate by a factor of thousands.

Conclusion. The pro-inflammatory effect on kidneys of many non-microbial toxicants can be realized through the formation of lipopolysaccharide by lysis of gram-negative bacteria. 


\section{Key words: kidneys; toxins; lipopolysaccharide; markers of inflammation.}

\section{INTRODUCTION}

The kidneys are very sensitive to various pathogens and pathological conditions caused by neuro-endocrine and alimentary disorders. Nephrotoxicity is detected by antibiotics, cytostatics, heavy metal salts, microbial toxins, hyperglycemia, a number of medicines [1-3].

In experimental conditions, the most effective way to detect pathological conditions of the kidneys is the direct determination of biochemical markers of inflammatory and dystrophic processes in the kidneys [4].

The aim of this study was a comparative study of the level of biochemical markers of inflammatory-dystrophic processes in the kidneys of rats under the action of different pathogens.

\section{MATERIAL AND RESEARCH METHODS}

Determination of the activity of the proteolytic enzyme elastase, which is produced by leukocytes [4], determination of the content of the final product of lipid peroxidation (LPO) of malonic dialdehyde (MDA) [4] was chosen as biochemical markers of inflammatorydystrophic processes.

As nephrotoxicants were selected hydrazine sulfate, known as a hepatotoxicant, corticosteroid prednisolone, known as an immunosuppressant, cyclophosphamide, which is a cytostatic, lincomycin, an antibiotic that inhibits the growth of probiotic bacteria [5] and lipopolysaccharide (LPS), intestinal endotoxin [6].

The experiments were performed on 91 Wistar rats in 7 series, each of which had two subgroups: control and experimental, which received for some time one of the toxicants. The total dose of the obtained toxicant is presented in table 1.

Table 1. Total dose of toxicants ( $\mathrm{mg} / \mathrm{kg}$ )

\begin{tabular}{|l|c|}
\hline \multicolumn{1}{|c|}{ Pathogens } & Total dose, $\mathrm{mg} / \mathrm{kg}$ \\
\hline Hydrazine sulfate, in / abdominal & 150 \\
\hline Prednisolone, per os & 105 \\
\hline Cyclophosphamide, in / abdominal, series I & 90 \\
\hline Cyclophosphamide, in / abdominal, series II & 90 \\
\hline Lincomycin with drinking water & 300 \\
\hline LPS, in / abdominal & 0,40 \\
\hline LPS, oral applications & 0,066 \\
\hline
\end{tabular}


After euthanasia of the animals in the kidney homogenate, the elastase activity and the MDA content were determined. To determine the specific pro-inflammatory activity, the percentage increase in the level of the biochemical marker per $1 \mathrm{mg}$ of toxicant was calculated.

Statistical processing of the results was carried out by conventional methods [7].

\section{RESULTS AND DISCUSSION}

Table 2 presents the results of the determination in the kidneys of elastase activity in rats treated with various nephrotoxicants. As can be seen from these data, all toxicants significantly increased the activity of elastase, and to the greatest extent hydrazine sulfate. But if you count the percentage increase in elastase activity per $1 \mathrm{mg}$ of pathogen, the strongest pro-inflammatory pathogen is LPS (Fig. 1). The latter exceeds the specific activity of hydrazine sulfate 135 times when administered intraperitoneally and 3550 times when administered by oral applications.

Table 2. Elastase activity in the kidneys of rats under the action of various pathogens

\begin{tabular}{|l|c|c|c|c|}
\hline \multirow{2}{*}{ Pathogens } & \multirow{2}{*}{$\begin{array}{c}\text { Total dose, } \\
\mathrm{mg} / \mathrm{kg}\end{array}$} & \multicolumn{2}{|c|}{ Elastase, mcat / kg } & \multirow{2}{*}{$\%$ increase } \\
\cline { 3 - 4 } & 150 & $0,25 \pm 0,03$ & $\begin{array}{c}0,34 \pm 0,02 \\
\mathrm{p}<0,05\end{array}$ & 36,0 \\
\hline Hydrazine sulfate, in / & 105 & $0,42 \pm 0,01$ & $\begin{array}{c}0,49 \pm 0,02 \\
\mathrm{p}<0,05\end{array}$ & 16,7 \\
\hline Pbdominal & 90 & $0,39 \pm 0,01$ & $\begin{array}{c}0,43 \pm 0,01 \\
\mathrm{p}<0,05\end{array}$ & 10,3 \\
\hline $\begin{array}{l}\text { Cyclophosphamide, in / } \\
\text { abdominal, series I }\end{array}$ & 90 & $0,48 \pm 0,02$ & $\begin{array}{c}0,61 \pm 0,04 \\
\mathrm{p}<0,05\end{array}$ & 27,1 \\
\hline $\begin{array}{l}\text { Cyclophosphamide, in / } \\
\text { abdominal, series II }\end{array}$ & 300 & $0,37 \pm 0,01$ & $\begin{array}{c}0,42 \pm 0,02 \\
\mathrm{p}<0,05\end{array}$ & 13,5 \\
\hline $\begin{array}{l}\text { Lincomycin with drinking } \\
\text { water }\end{array}$ & 0,40 & $0,46 \pm 0,02$ & $\begin{array}{c}0,53 \pm 0,02 \\
\mathrm{p}<0,05\end{array}$ & 13,0 \\
\hline LPS, in / abdominal & 0,066 & $0,32 \pm 0,01$ & $\begin{array}{c}0,41 \pm 0,02 \\
\mathrm{p}<0,01\end{array}$ & 28,1 \\
\hline LPS, oral applications & & & & \\
\hline
\end{tabular}

Our data on the extremely high nephrotoxicity of LPS coincide with the data on the high hepatotoxicity and mucosotoxicity of LPS [8]. The very high difference in the effect of LPS on renal elastase at different routes of administration can be explained by the fact that the stomatogenic pathway provides rapid transport of the pathogen into the bloodstream, bypassing the hepatic barrier. It is known that the liver neutralizes almost $95 \%$ of LPS, which comes from the intestine [9]. 


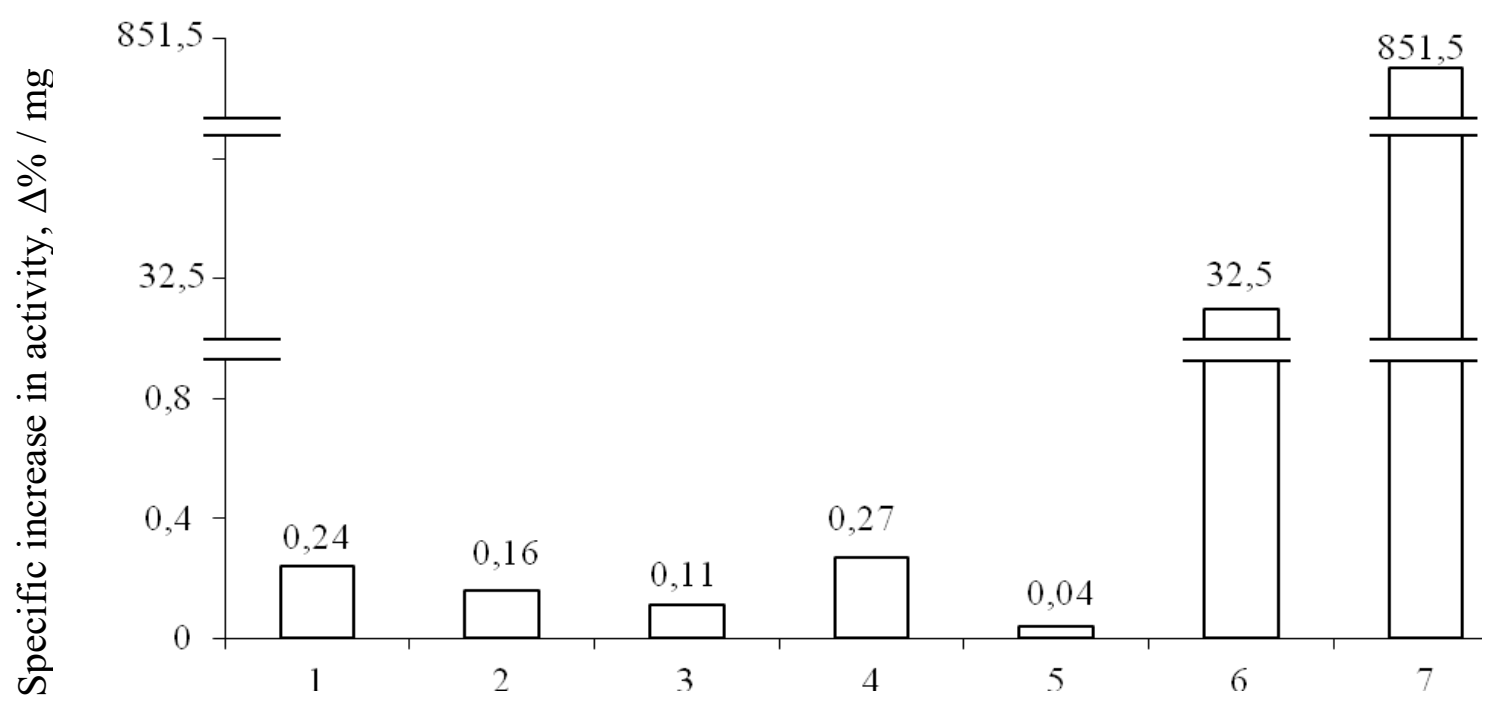

Fig.1. Specific increase in elastase activity $(\Delta \% / \mathrm{mg})$ in the kidneys of rats under the influence of various pathogens ( 1 - hydrazine sulfate, 2 - prednisolone, 3 - cyclophosphamide, 4 - cyclophosphamide, 5 - lincomycin, 6 - LPS in / abdominal,

7 - LPS applications on oral mucosa)

Table 3 presents the results of determining the effect of pathogens on the content of MDA in the kidneys of rats.

Table 3. The content of MDA in the kidneys of rats under the action of various pathogens

\begin{tabular}{|l|c|c|c|c|}
\hline \multicolumn{1}{|c|}{ Pathogens } & $\begin{array}{c}\text { Total dose, } \\
\mathrm{mg} / \mathrm{kg}\end{array}$ & \multicolumn{2}{|c|}{ MDA, mmol / kg } & \multirow{2}{*}{ \% increase } \\
\cline { 3 - 4 } & 150 & $28,0 \pm 2,6$ & $\begin{array}{c}43,1 \pm 0,8 \\
\mathrm{p}<0,001\end{array}$ & 53,9 \\
\hline Hydrazine sulfate, in / & 105 & $18,2 \pm 1,2$ & $\begin{array}{c}23,7 \pm 1,2 \\
\mathrm{p}<0,05\end{array}$ & 30,2 \\
\hline abdominal & 90 & $46,0 \pm 3,0$ & $\begin{array}{c}56,5 \pm 3,6 \\
\mathrm{p}<0,05\end{array}$ & 22,8 \\
\hline $\begin{array}{l}\text { Cyclophisolone, per os } \\
\text { abdominal, series I }\end{array}$ & 90 & $37,4 \pm 2,6$ & $\begin{array}{c}48,6 \pm 3,8 \\
\mathrm{p}<0,05\end{array}$ & 29,9 \\
\hline $\begin{array}{l}\text { Cyclophosphamide, in / } \\
\text { abdominal, series II }\end{array}$ & 300 & $51,8 \pm 0,09$ & $\begin{array}{c}57,1 \pm 2,6 \\
\mathrm{p}<0,05\end{array}$ & 10,2 \\
\hline Lincomycin with drinking & & $36,8 \pm 1,0$ & $\begin{array}{c}40,9 \pm 1,3 \\
\mathrm{p}<0,05\end{array}$ & 11,1 \\
water & 0,40 & $65,9 \pm 2,3$ & $\begin{array}{c}78,4 \pm 3,7 \\
\mathrm{p}<0,05\end{array}$ & 19,0 \\
\hline LPS, in / abdominal & 0,066 & & & \\
\hline LPS, oral applications & & & & \\
\hline
\end{tabular}


These data show that all pathogens significantly increase the content of MDA, and to the greatest extent hydrazine sulfate. But in determining the specific pro-inflammatory activity was most effective LPS (Fig. 2). Under conditions of intraperitoneal administration, LPS was 76 times higher than the effect of hydrazine sulfate, and after oral administration 1600 times.

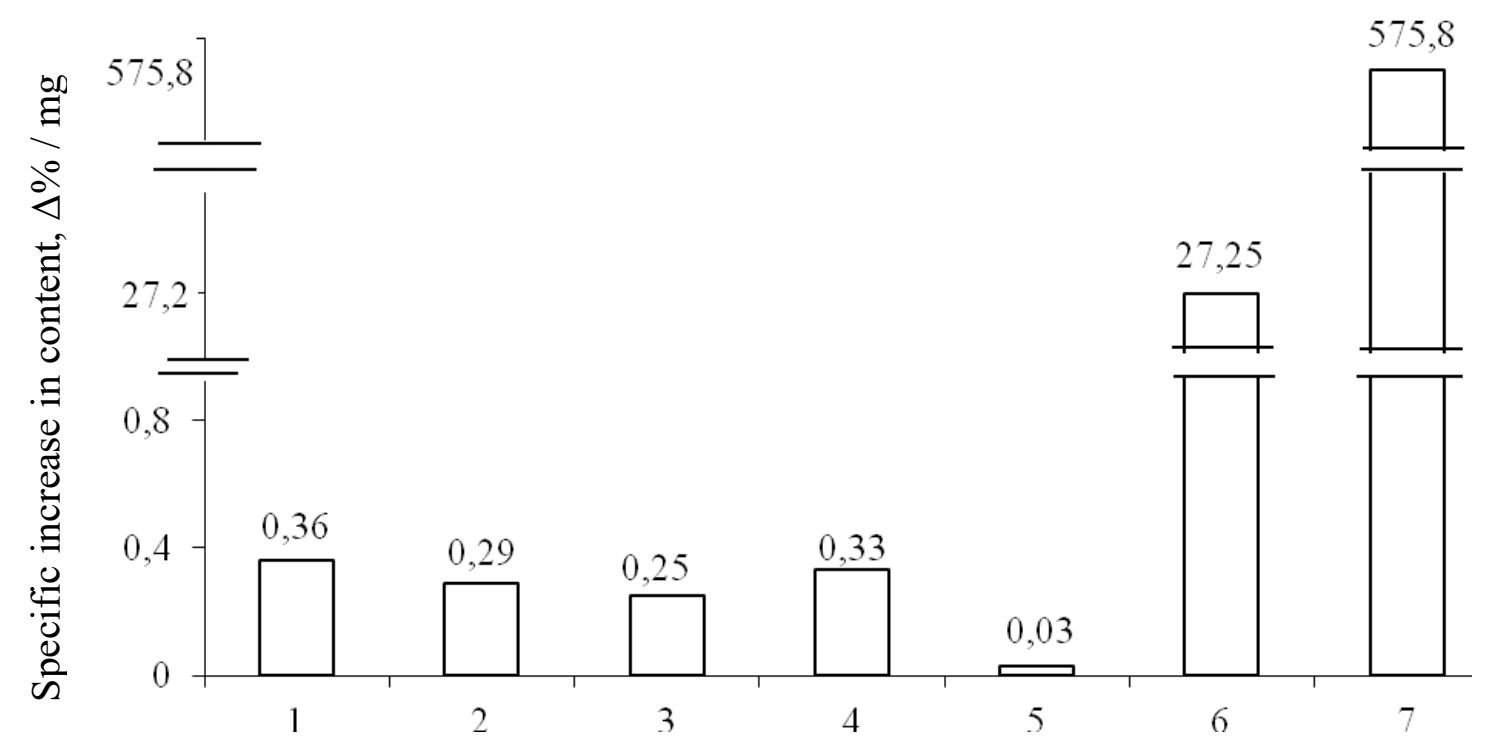

Fig. 2. Specific increase in the content of MDA $(\Delta \% / \mathrm{mg})$ in the kidneys of rats under the influence of various pathogens (1-7 - see Fig. 1)

Of all the pathogens, lincomycin showed the lowest specific anti-inflammatory activity: 6 times less on the effect on elastase and 12 times less on the effect on MDA.

Our data confirm the idea of the crucial role of microbial factor, namely intestinal endotoxin (lipopolysaccharide) in the development of inflammatory-dystrophic processes in the kidneys. Lipopolysaccharide is produced by gram-negative bacteria, which make up the majority of endogenous microbiota in the body [10. 11]. To isolate it from bacterial membranes, it is necessary to carry out lysis of bacteria. There is a hypothesis that all pathogenic factors carry out their pro-inflammatory action in the body due to activation of bacteriolysis, which leads to the release of LPS, which performs a pro-inflammatory effect.

The presence of bacteria in the organs and tissues of the animal body is well known, and the surface area of all gram-negative cells can significantly exceed the surface area of somatic cells. Therefore, the probability of bacteriolysis under the influence of non-microbial 
pathogens may be a decisive factor in the pathogenesis of inflammatory-dystrophic processes that occur in intoxications of the body.

In the world of this hypothesis, the very low pro-inflammatory effect of the antibiotic lincomycin becomes clear, because it necessarily reduces the number of bacteria in the body.

\section{Conclusions}

1. All pathogens (hydrazine sulfate, prednisolone, cyclophosphamide, lincomycin and lipopolysaccharide) cause the development of inflammatory-dystrophic processes in the kidneys, as evidenced by increased levels of biochemical markers of inflammation - elastase activity and MDA content.

2. Specific proinflammatory activity (percentage increase in the level of markers per 1 mg of pathogen) was extremely high in lipopolysaccharide.

3. The stomatogenous route of administration of lipopolysaccharide showed a stronger pro-inflammatory effect than in / abdominal.

4. The hypothesis of the possibility of realization of pro-inflammatory action of nonmicrobial pathogens due to bacteriolysis of tissue gram-negative bacteria is put forward.

\section{REFERENCES}

1. Smirnov AV, Dobronravov VA, Bodur-Oorzhak ASh [and others]. Epidemiology and risk factors for chronic kidney disease: regional level of the General problem. Therapeutic archive.. 2005; 77(6): 20-27. (in Russian)

2. Stepan VT. The development of inflammation and dysbiosis in kidneys and bladder wall in rats at stomatogenic endotoxemia. Dentistry Bulletin. 2016; 2(95): 6-9. (in Russian)

3. Sanyaolu A, Okorie C, Annan R [and others]. Epidemiology and management of chronic renal failure: a global public health problem. Biostatistics Epidemiolmoil J. 2018; 1(1): 11-16.

4. Levitsky AP, Gozhenko AI, Stepan VT [and others]. Biochemical markers of inflammatory-dystrophic and dysbiotic processes in the kidneys in experimental pathology: guidelines.Odessa, 2020: 20. (in Ukrainian)

5. Levitsky AP, Selivanskaya IA, Tsiselskiy YuV [and others]. The method of simulation of dysbiosis (dysbacteriosis). Patent of Ukraine 31012. IPC (2006) A61P 31/00. Application number u 200711609. Date of filling: 22.10.2007. Publ.: 25.03.2008. Bul. № 6 . (in Ukrainian)

6. Levitsky AP. Stomatogenic endotoxinemia. Journal of the National Academy of Medical Sciences of Ukraine. 2013; 19(4): 490-493. (in Russian) 
7. Truhacheva NV. Mathematical Statistics in biomedical research using application package Statistica. Moskow, GJeOTAR-Media, 2012: 379. (in Russian)

8. Levitsky AP, Gozhenko AI, Stepan VT [and others]. Dysbiotic aspects of pathogenesis and antidysbiotic prophylactics of experimental nephropathy. Journal of Education, Health and Sport. 2017; 7(6): 1124-1136. (in Russian)

9. Levitsky AP. Disbiotic syndrome: etiology, pathogenesis, clinic, prevention and treatment. Dentistry Bulletin. 2019; 10(special issue): 14-20. (in Russian)

10. Bocharov AV, Makarenko OA, Semik LI [and others]. The role of intestinal dysbiozis in infringement of the function of the liver of rats after antibiotic therapy. Journal of Education, Health and Sport. 2018; 8(11): 518-524.

11. Gozhenko A. I. Advantages of high olein sunflower oil over palm oil according to biochemical research results / A. I. Gozhenko, A. P. Levitsky, V. T. Stepan, I. P. Pustovoit, N. S. Badiuk, A. K. Maslyukov - PhOL - PharmacologyOnLine - N 2. - P. 293-301. https://pharmacologyonline.silae.it/files/archives/2020/vol2/PhOL_2020_2_A028_Gozhenko. pdf 